inevitable that one is in the end left with a stronger impression of the bizarre and intriguing examples, rather than any penetrating understanding of the fundamentals. The complete lack of documentation here is at times frustrating - so much of animal behaviour is, by its very nature, ephemeral and elusive, and observations are difficult to repeat sufficiently to become the basis of a sound generalisation. It is claimed, for example (p. 114) that it is 'a fundamental principal in zoology that predators do not hunt in the vicinity of their core area'. Without evidence that this is so, or any explanation of why it should be so, such a statement must join the many in a limbo between fact and speculation that makes behaviour such a difficult subject to penetrate.

G. B. CORBET

Mammals of Thailand, by Boonsong Lekagul and Jeffrey A. McNeely. Association for the Conservation of Wildlife, 4 Old Custom House Lane, Bangkok 5, US \$49.

To increase your knowledge of Asian mammals, you can do no better than to invest in this splendid book, In 800 -plus pages (weighing $3 \mathrm{~kg}$ ) of facts, figures and illustrations it covers 264 mammal species, most of which, despite the title, range far beyond the boundaries of Thailand. The book is of interest and value to anyone interested in the fauna of the Oriental Region.

To those familiar with conservation in SE Asia it will be no surprise to learn that it is the brainchild of Dr Boonsong Lekagul, the distinguished naturalist who has done much to protect and popularise the fauna of Thailand and neighbouring countries; it is surely only a matter of time before his conservation efforts are recognised with a major international award. He and Jeff McNeely have produced a reference work that is not only impressive in its scope but also very readable. After an introduction covering the geological past of Thailand, habitat types, zoogeography and current legislation concerning wildlife, they give a comprehensive introduction to and discussion of all orders and families. Every species is illustrated with either a photograph or drawing, and the text gives detailed information on its taxonomy, distribution (with map), morphology (including dental and cranial characters), and whatever is known about the animal's ecology and behaviour. I am particularly pleased with the section on bats, a group which is often a mystery to the non-specialist and consequently frequently omitted from guides. With its help we are even beginning to make sense of the aerial fauna of Sulawesi!

Fieldworkers and interested amateurs alike will find this book excellent value. It is expensive, but buyers can console themselves with the thought that it is a work of reference that will never be outdated. Jeff McNeely is now hard at work on an even more ambitious (and weightier?) Mammals of Indonesia which will certainly prove another 'must' for those fascinated by the wildlife of SE Asia. Better reinforce your bookshelves now!

KATHLEEN MACKINNON

\title{
India's Wildlife in 1959-70, by M. Krishnan. Bombay Natural History Society,
} Rs 30.

This volume brings together the author's four reports published in the Journal of the Bombay Natural History Society in 1971-2. They were based mainly on his field notes of 12 years, including two final years of intensive ecological survey of wild mammals in peninsular India made possible by a fellowship from the Jawaharlal Nehru Memorial Fund. The significance of this 12-year period is that photographic documentation (242 illustrations in this volume, from about 6000 used in the study) was extensively employed as evidence to reinforce observation. Although the author considers that the primary object of the survey was to assess the impact of the changing environment on the wildlife, he gives much original information on the morphology and behaviour of 
some of his study animals. Ecological factors considered include not only climate, flora and territory and the inter-relationship of the animals, but what is of far greater importance in the Indian context, the impact of man.

Descriptions of the study areas precede the discussion on the problems of 33 wild mammals in coming, or failing to come, to terms with their shrinking and ravaged habitats. Some, like the lion-tailed monkey, tiger, wild buffalo, blackbuck and barasingha, have suffered grievously; a few like elephant and chital have adapted bravely. But it could be that the worst is still to come. There are extended sections on elephant and gaur, on which Krishnan's knowledge in peninsular India is unrivalled. $\mathrm{He}$ concludes inescapably that the effect of human disturbance on the wildlife and plants today has been overwhelming, but, sadly, is still the least appreciated major factor in conservation in India.

I had read the reports as they had been published; reading them again the integrity of the research and of the presentation of results made as deep an impression as before.

B. SESHADRI

The Handbook of British Mammals, 2nd edition, edited by G. B. Corbet and H. N. Southern. Blackwell Scientific Publications, for the Mammal Society, $£ 9.75$.

The first edition of this Handbook in 1964 so stimulated the study of our mammalian fauna during the next twelve years that the accumulated information makes the second edition more than twice as large. The original Part I on the biology of British mammals has been condensed to a chapter on the Study of British Mammals 1964-1976, in order to make room for the enormously expanded systematic accounts. The editors have enlisted a team of specialists to deal with the groups and species they have made their special study, and the result is a handbook unsurpassed in quality by any other covering a similar area.

Information about each species is set out on a standard plan so that reference to any point required is easily found. All the excellent photographs and drawings are selected to show important points in identification, structure or behaviour, not just as ornamental embellishments, and there is a distribution map for each species, except for the Cetacea. The text is well documented with references to original sources listed in voluminous bibliographies, and there is a full index as well as a short glossary of words not found in the Concise Oxford Dictionary.

It might be thought that a handbook of this nature would be useful for reference but too formalised for straightforward perusal. On the contrary, the systematic accounts, in addition to the introductory chapter, make fascinating reading for any naturalist. The editors, contributors, and publishers are to be congratulated on producing a splendid book that will remain a standard for many years.

L. HARRISON MATTHEWS

\section{The Savage Paradise: the Predators of Serengeti, by Hugo van Lawick. Collins,} $£ 15$.

This is a wonderful book, concerned mainly with portraying the predators of the Serengeti and the Ngorongoro Crater in their favoured habitats. The author has worked as a wildlife photographer in this region over a period of 15 years, and is widely known for the skill and sensitivity with which he uses his camera. Years and years of sitting quietly watching animals all day long have given him an extensive knowledge of their behaviour, what the pattern is and what follows in sequence; he has developed a strong and almost intuitive sense of what will happen next. This faculty of anticipation and timing is one reason why his animal pictures are outstanding, as demonstrated by the 150 in this book, almost all in colour, which represent the pick of goodness knows how many taken over the years.

In planning the book, Collins clearly rose to the challenge and set out to provide a setting worthy of the pictures: fine thick paper, ultra-large pages, excellent colour 